\title{
Examining Equity in Ghana's National REDD+ Process
}

\section{Introduction}

Reduced Emissions from Deforestation and Forest Degradation (REDD+) is a voluntary mechanism under the United Nations Framework Convention on Climate Change (UNFCCC). It incentivizes forested developing countries employing new strategies to reduce forest loss in order to cut the carbon emissions associated with such loss. The mechanism is aimed at mitigating the $12-17 \%$ of total global greenhouse gas emissions attributable to forest loss (Boucher et al., 2014). REDD+ comprises: enhancement of forest carbon stocks; conservation; sustainable forest management; reducing forest degradation; and reducing deforestation.

Under the UNFCCC, many tropical forested countries have signed up to REDD+. New initiatives such as the World Bank Forest Carbon Partnership Facility (FCPF) and the United Nations Collaborative Programme (UNREDD), have emerged in concert with REDD+ to fund these countries' early activities, as the UNFCCC debates the financial architecture to support the mechanism, including via the Green Climate Fund. Ghana is one of 197 countries to have ratified the UNFCCC, and is actively participating in REDD+. As a relatively less industrialized country, but with a growing population, emerging economy and development, Ghana's land use sector is a key consideration in its greenhouse gas emissions (MEST, 2010).

Ghana aims to reduce its overall emissions over the next 10 years by $40 \%$ (FC, 2016). It aims to achieve this in tandem with addressing ecosystem service threats and ensuring environmental integrity. REDD+ governance and policy in Ghana is a collective action problem as the country commences its full programme. Collective action in this context is understood as the basic condition for achieving effective governance outcomes in the commons (Ostrom, 1990). There is an opportunity to contribute to knowledge, necessary in shaping Ghana's process of effectively managing REDD+ for equitable and effective outcomes, and reducing the social risks and costs of REDD+ (Ribot and Larson, 2012).

The aim of this paper is to examine how equity features in REDD+ in Ghana, based primarily on REDD+ stakeholder perceptions and document review. While equity is relevant at all spatial scales, this paper focuses on Ghana's national level institutions, rather than the international UNFCCC level as treated by Ituarte-Lima et al. (2014) in their study. This national focus is particularly crucial given that the UNFCCC stipulates the "adoption of a national approach to reporting on REDD+, that assigns national governments the ultimate authority in governing REDD+ actions" (ItuarteLima et al., 2014; p. 293).

Accompanying new governance mechanisms such as REDD+ are theoretical debates around how such mechanisms impact equity, and thereby either entrench or successfully address existing inequalities and structural causes of poverty (McDermott et al., 2013). There are many ways to approach equity in REDD+ (e.g. those of Quesada-Aguilar and Franks, 2015 or Rantala et al., 2015). However, we draw on McDermott et al.'s (2013) 'equity framework', specifically because it provides a comprehensive and systematic approach to analyzing how institutions mediate equity. The framework distinguishes several dimensions of equity, including distributive, procedural and contextual equity. 
We apply McDermott et al.'s 'equity framework' empirically to: explore REDD+ governance and policy processes in Ghana, including institutional set-up; to ask questions of those who count in REDD+ governance; and understand how the state mediates actor interests and relations in implementing REDD+. We examine the inclusion and exclusion of actors, identify important decision making processes, identify which actors matter in defining implementation activities and who faces what costs and risks and enjoys what benefits. We further discuss the extent to which the Ghana REDD+ process addresses equity and we do this premised on the importance of REDD+ doing no harm, promoting net benefits and being effective in achieving its objectives (RECOFTC, 2015).

\section{Adapting the Equity Framework to REDD+ in Ghana}

Ghana has been endowed with natural resources including an estimated 8 million hectares of forest, which has dwindled at $2 \%$ per annum since the 1990 s to an area covering 1.6 million hectares (MLNR, 2012; Marfo et al., 2013). Ghana's forests are divided into 'reserves' and 'off-reserves'. The 'reserves' are governed by the state under a prohibitive 'command and control' approach and zoned into $80 \%$ production reserves and $20 \%$ protection reserves. 'Off-reserves' across the country are managed under various arrangements including collaborative approaches with communities and farmers. Reports indicate that Ghana has lost, and is continuing to lose, forest cover at an alarming rate in the 'off-reserves', amounting to more than it has in the 'reserves' (FC, 2010; Marfo et al., 2013). This is mainly due to unsuitable exploitation practices including logging that exceeds the annual allowable cut for timber (FC, 2010).

Forests play a significant role in the economic development of Ghana both informally and formally. For instance, formal logging contributed 3.7\% of gross domestic product in 2009, and it is estimated that the sector employs 120,000 people (MLNR, 2012). Ghana's forests informally serve as a source of livelihood including non-timber forest products for subsistence and commercial purposes, hunting, chain-saw operations to supply domestic timber demand, small-scale carpentry, and herbal services. With a population of 25 million people and an estimated 11 million forest area dwellers, out of which 2 million depend on forests and wildlife for their livelihood (MLNR, 2012). Ghana's dwindling forest remains a valuable natural resource that demands new forms of sustainable management (Lockwood et al., 2010) such as REDD+.

REDD+ focuses on the extent to which it can reduce emissions (effectiveness) at a minimum cost (efficiency), while still achieving fair distribution of costs and benefits (equity)(Quesada-Aguilar and Franks, 2015; Angelsen et al., 2012). REDD+ therefore requires a diversion from business-as-usual to achieve emission reductions, but in an equitable fashion that provides net-benefits without causing harm, and contributes to poverty reduction in both process and outcomes. To understand the realities associated with REDD+ implementation, we investigate equity in Ghana's REDD+ readiness process. Equity has various dimensions and the equity framework introduced by McDermott et al. (2013) attempts to identify and bring together these dimensions in an integrated, systematic and rigorous way (see Figure 1 below). McDermott et al. (2013) elaborate their framework on the scalar dimension of equity, the goal of equity and the parameter setting process. Their framework sets the scene for questions of why equity matters, who counts, and what counts as equity in the context of changing global values for local ecosystem services. 
The equity framework helps to clarify the relevance of equity goals and that goals may incur costs. For example, a scheme that sets out to alleviate poverty through carbon forests can come with a cost of excluding access for some people (PennaFirme and Brondizio, 2007). Understanding the parameters of equity demonstrates relevance of process for deciding goals, targets and contents of REDD+, as a way to clarify who is included or excluded from intervention, and how that has relevance for policy and practice.

McDermott (2013) has also applied the framework to compare priorities and tradeoffs on different environmental and social certification schemes. The framework reveals existing variation in how environment or equity are prioritized across supply chains according to the way that equity is framed and standards are safeguarded. Overall the equity framework helps to identify a general need for further deliberative strategies for participation in forest certification schemes. Ituarte-Lima et al. (2014) also apply the equity framework to assess key articles of the UN Framework Convention on Climate Change, as well as Indonesia's Constitution, its REDD+ strategy and selected legislation. They found value in adopting such a comprehensive framework to situate detailed analysis of specific REDD+-related laws within their broader legal and fiscal contexts from international to national and local.

In this instance the framework helps us examine Ghana's REDD+ governance systems within the dimensions of:

- Procedural equity - This dimension refers to decision-making and how it features in the uptake of new ideas and approaches by local people in the context of REDD+. It considers which marginalized groups are recognized, who is included and who is left out (McDermott et al., 2013; REDD-net, 2011).

- Distributive equity - This dimension addresses the risks, costs and distribution of benefits, in particular to marginalized groups e.g. women, the landless, migrant farmers etcetera, and the core 'benefactors' of REDD+. It sheds light on the intended basis for benefits distribution and the impacts that the costs and benefits have (REDD-net, 2011).

- Contextual equity - This dimension examines pre-existing social, political and economic conditions, such as tenure, land rights and political structures, that limit or enable people's access to decision-making procedures, resources and benefits (McDermott et al., 2013). In other words, it addresses how level the playing field is. With respect to REDD+, this includes earlier processes, historical forest management institutions, practices, and existing policies and laws. Equitable participation cannot lead to equitable outcomes on an uneven playing field.

All three dimensions are relational, with context influencing the procedures that take place and the distributions for stakeholders of costs borne and benefits accrued. There are other essential elements that overarch the three dimensions. These are examined within the exploration of equity in Ghana's REDD+ process:

- Equity parameters: This refers to what constitutes equity and how it comes to be embodied in the process. It is process oriented with a focus on the scale of decision-making and who is included or excluded from making decisions. 
- Goal of equity: This concerns why the equity parameters are established. It draws out the essence of why the programme has to include equity considerations such as maximizing equity, improving equity, doing no harm or eliminating equity altogether (REDD-net, 2011).

- Who counts: This refers to who is considered a target of the equity parameters that are set, and how they come to be targets. In other words, the targets encompass relevant stakeholders - those that affect, and are affected by, the programme.

Exploring the Ghana REDD+ process using this framework is a way to contribute to the effectiveness of a REDD+ programme that does not cause harm but inures netbenefits for relevant stakeholders and contributes to the low-carbon development pathway of the country. There are serious concerns around the scale at which equity needs to be addressed, as what is inequity at one scale may lead to equity at another. For instance, McDermott et al. (2013) say that payment for environmental service schemes emphasize environmental outcomes at the neglect of poverty reduction, and thus may lead to inequitable outcomes at the forest community level but globally benefit the poorest peoples by the reduction in catastrophic green house gases.

Figure 1. Equity Framework (McDermott et al., 2013) goes here

To date a number of REDD+ case studies focus on equity with inspiration from broader justice frameworks, yet with similar entry points to McDermott's framework. For example, Nathan and Pasgaard (2017) situate analysis of REDD+ within a broader context of efficiency, effectiveness and equity in Northern Cambodia. They found tensions between objectives of creating efficient and effective financial value from carbon stored in trees through the private market and the social equity considerations that are often overlooked. REDD+ projects implemented in areas of limited statehood are unlikely to be effective, efficient, and equitable at the same time they note. They also identified the need for more studies on REDD+ projects with different approaches that could lead to different conclusions. Similarly, Isyaku et al (2017) investigate the dimensions of justice in REDD+ in West Africa by paying explicit attention to transparency, equity and legitimacy (TEL) criteria to examine justice considerations in REDD+ implementation in Nigeria and Ghana. Their findings show that including the normative elements of justice provides important insights into how REDD+ might both enable and disable justice for local people.

Fraser (2001) draws attention to the work of Taylor (1994) and Honneth $(1992,1995)$ on recognition, as "being recognized by another subject is a necessary condition for attaining full, undistorted subjectivity. To deny someone's recognition is to deprive her or him of a basic prerequisite for human flourishing" (Fraser, 2001: p.26). Schlosberg and Carruthers (2010) demonstrate the value of focusing on broad, integrated, and pluralistic discourse of justice among indigenous peoples-one that can incorporate a range of demands for equity, recognition, participation, and other capabilities into a concern for the basic functioning of nature, culture, and community. Forsyth and Sikor (2013) go a step further and examine justice in the 
values, knowledge, access and property rights relating to forests. They critique John Rawls' principles of fair allocation to known actors as insufficient and argue instead for Amartya Sen's more deliberative and inclusive vision of justice that focuses on how different users experience different benefits, and seek to achieve multiple objectives together. They argue that approaches to redistribution and recognition do not acknowledge the diversity of concerns about which aspects of forest benefits are to be allocated and highlight the rights in forest governance beyond indigenous peoples.

\section{Research design \& Methods}

With REDD+ being a contemporary and evolving mechanism, an exploratoryqualitative case study serves as an appropriate approach with which to launch an indepth analysis of empirical findings (Yin, 2014; Baxter and Jack, 2008). With complex and integrated real world issues such as poverty reduction, livelihood security, effective emission reduction and resource rights/access surrounding the performance of REDD+, our adoption of a case study makes it possible to consult various data sources. Ghana is chosen as the case study country based on its pioneering status in commencing REDD+ readiness under the FCPF in 2008. In addition, empirical REDD+ literature on Anglophone West Africa is limited, compared to other regions (Saeed et al., 2017). However, in the last couple of years, an increasing number of studies on West Africa have emerged. For example, Asiyanbi (2016) on political ecology of REDD+ in Nigeria; Arhin (2015) on the progress, prospects and challenges in Ghana's REDD+ process; Asiyanbi et al. (2017) on politics around REDD+ design and implementation in Ghana and Nigeria; Isyaku et al. (2017) on framing justice in REDD+ governance; and Tilahun et al. (2016) on REDD+ opportunity costs in Ghana. This study, by researching equity in Ghana's national REDD+ policy process, contributes novel insights into the region's progress with REDD+. The study presents an interesting case to which the application of the 'equity framework' helps ascertain the balance between the intention to establish and attain clear equity goals for REDD+, and stakeholder perspectives on the actual outcomes.

This study reviews literature pertaining to REDD+ in Ghana including legal texts, documents, meeting reports and consultancy reports on Ghana's forest sector. These include the 1992 Constitution of Ghana; 2012 Forest and Wildlife Policy (FWP); 2013 National Climate Change Policy; REDD+ Benefit Sharing Consultancy Report; 2016 REDD+ Strategy; Social, Environmental and Strategic Assessment report (SESA); and the REDD+ Readiness Preparation Proposal (R-PP).

Primary data was gathered from mid July to late September 2014 and February to March 2016, employing criterion and snowball sampling approaches (Teddlie and $\mathrm{Yu}, 2007)$ to identify relevant interviewees in Ghana. Criterion sampling, as the initial approach, allowed the study to profile experts and authority figures identified from key Ghanaian REDD+ forestry documents such as the R-PP. The interviewees profiled assisted in the identification of other relevant actors not captured in the original list. A total of 35 face-to-face interviews were held with REDD+ stakeholders including representatives of the private sector, government officials, civil society organizations (CSOs), national level traditional authorities and donor communities.

All the interviews were audio-recorded, transcribed and exported to the QSR-NVivo software package. NVivo was used to organize interviews in one place and code raw field data into themes. Coding in NVivo allowed the data to be broken down into manageable bits, given the large amount of data generated from 35 interviews each 
averaging 50 minutes. NVivo was useful in cross-referencing anecdotal evidence with electronic documents.

We adopt a reflexive approach to research analysis, to make sense of the findings; a process that involved the interpretation of what was said in interviews and written in documents, while reflecting on what positions, previous knowledge and understanding we, as researchers, brought to the study (Symon and Cassell, 2012).

\section{Results}

\subsection{Process: How are the parameters of equity set?}

In Ghana, the Forestry Commission (FC) under the Ministry of Lands and Natural Resources (MLNR) serves as the key authority for the national REDD+ process. The FC's designated REDD+ Unit initiated the process by submission of a Readiness Plan Idea Note (R-PIN) to the World Bank in 2007. The R-PIN gave insight into land use patterns, drivers of deforestation and institutional arrangements. The World Bank accepted Ghana's R-PIN in July 2008, thereby initiating the development of the Readiness Preparation Proposal (R-PP) document.

Currently, Ghana's REDD+ policy process, as per the directive of the World Bank in 2010, has strong political backing at the highest level of cabinet. The platform chaired by the Vice-President is known as the Environment and Natural Resources Advisory Council (ENRAC). ENRAC provides guidance and direction on policy coordination with respect to various sectors and the pursuit of sustainable development vis-à-vis the environment and natural resources. Beneath ENRAC is the Technical Coordinating Council Plus (TCC+), which makes decisions for the FCPF REDD+ readiness and the REDD+ up-scaling facility, the Forest Investment Programme (FIP). Under TCC+, is the National REDD+ Working Group (NRWG), a multi-stakeholder committee at ministerial level that has created the opportunity for all key stakeholders to be engaged in setting the parameters for REDD+ activities. Plans are developed by the REDD+ Secretariat and submitted to the NRWG for approval before implementation. However, It was pointed out by a number of interviewees that the NRWG...

"...meetings are hardly summoned. And once in a while when meetings are scheduled they have been last minute to the displeasure of others... the working group is not that active" (CSO official B, 2014).

Despite this shortfall, there are 7 sub-working groups including policy and governance, consultation and participation, monitoring, reporting and verification, which operate much more frequently. The aggregated members of the sub-working groups constitute the NRWG. Furthermore, the REDD+ design process in Ghana has relied heavily on consultants. According to the fieldwork findings...

"the $[R E D D+]$ secretariat does not always use its mechanism to do things when they realize that there is an obvious gap. They involve or try to draw expertise across board to help them push certain issues forward so I think... that brings in lots of ideas... experts within this space bring in the knowledge"(Consultant B, 2014).

Consultants were commissioned to develop the national REDD+ strategy, the grievance redress mechanism, the benefits sharing scheme, monitoring, reporting 
and verification protocols and other REDD+ components. The demand for (new) knowledge under REDD+, means consultants as experts in particular areas are essential in bridging capacity gaps of the $\mathrm{FC}$ and other state institutions vis-à-vis the scientific and technological requirements for rolling out REDD+ (FC official A, 2014). Despite the value attached to consultants, some respondents alluded to some commissioned consultants having been bad choices as they lacked the requisite capacity. It was evident from the field that some consultancies failed to meet the expected outcomes of their assignments. In reference to one of the consultancies, official $A$ from the FC indicated that...

\begin{abstract}
"there were major weaknesses in the work that was submitted by consultant organization C. I think, looking back, they didn't have the capacity to do this kind of job and when they made the bid for the assignment, in their proposal they gave us [FC] an impression that they had a very competent team and that they could also tap into the global network of consultant organization C... clearly the people who were leading this work didn't have the qualification so it was a consultancy gone wrong".
\end{abstract}

In this sub-section, we posed the question, how are the parameters of equity set in the Ghana REDD+ process? In summary, we discovered that the design process for REDD+ in Ghana is set around a complex use of various platforms at several levels that seek to promote cross-sectorial, inter-ministerial and multi-stakeholder involvement, including high political support. There are difficulties surrounding the process such as infrequent meetings of some platforms, and stakeholders who are actually affected, such as forest communities, having limited or no role in policy discussions. There is also high reliance on consulting firms, which arguably impacts the equity goal set, and has implications for various stakeholders. The effectiveness of the process via which REDD+ and inherent equity parameters are established is questionable.

\title{
4.2 What is the equity goal? Why that goal?
}

The Ghana R-PP contains a Social and Environmental Strategic Assessment (SESA), which states a commitment to "do no harm" and enhance positive REDD+ benefits relating to society, livelihoods, governance, biodiversity and the environment. The R-PP includes equity in promoting national socio-economic development, accountability and due process for all (FC, 2010). This aligns with the 2012 Forest and Wildlife Policy, which guides all interventions, programmes, and actors within the forest sector. It upholds as its over-arching guide, the need to enhance the quality of the socio-economic life of all stakeholders. The current Forest and Wildlife Policy takes advantage of new opportunities such as REDD+ and shifts the initial policy focus on timber for economic development to one in which environmental and social demands are of concern. Yet, the policy has been criticized by a cross-section of interviewees including a conservation NGO official who said...

"Here, policy is always last to happen. It's like it's not the policy that is leading us and guiding us... things are happening and then we try to integrate it into the policy... if you look at the new Forest and Wildlife Policy, I just think its empty".

Equity is sought across the country with respect to securing optimum welfare among forest stakeholders; decision-making and ensuring adequate means of livelihoods; 
economic, social and environmental aspects of development across the board; and doing no harm at the expense of another (FC, 2010; MLNR, 2012). For example, Ghana's 2016 REDD+ strategy prioritizes gender mainstreaming to ensure that negative impacts on women are eliminated. Also, proposed REDD+ benefit-sharing models were examined in relation to equity in the consultancy report. According to an FC official, communities have to be incentivized and...

"given the assurance that such a programme would also yield them economic benefits as well as environmental benefits that would go to favour them".

However, another interviewee (Consultant D) questioned the goals achievable under Ghana's REDD+ regime:

"If carbon sequestration will bring in carbon revenues, does that also ensure poverty reduction? So I believe this is where some of the vulnerability aspects of smallholders will come in and perhaps the strategy will also have to see how best to accommodate and find solutions".

The goal to reduce emissions via REDD+ is rooted explicitly in policies that aim to ensure no-harm is done in the socio-economic lives of the local forest dwellers. This equity goal is a baseline for the measurement of REDD+ achievements in Ghana.

What then is the equity goal and why that goal in the Ghana REDD+ process? In pursuing the objective to reduce forest emissions, the equity goal is to safeguard and also improve the welfare of the various REDD+ stakeholders across the nation. In so doing, the goal serves as a benchmark against which the Ghanaian state can measure its progress in pursuit of REDD+.

\subsection{Who is treated as a subject of equity?}

FWP (2012) seeks to establish a sector that is sustainable and provides continuous benefits for present and future generations. In order to achieve collective ownership and successfully reduce emissions, the R-PP plans to ensure improved understanding of REDD+, including the roles/responsibilities and opportunities REDD+ offers to each stakeholder group (FC, 2010). The R-PP considers the immediate stakeholder groups to be the government, private sector, development partners and civil society, with a focus on forest fringe communities. In the peculiar case of Ghana, chiefs are mentioned as a stakeholder group. These chiefs are recognized by the 1992 Constitution of Ghana as formal institutions, and considered to be key leaders in framing REDD+ policy, actions and measures, as they control lands on behalf of their communities (FC, 2010). This suggests that chiefs wield certain influences that affect the equity considerations of REDD+. Some fieldwork respondents corroborated the findings of the R-PP, expressing views that:

"The FC... are the managers of these projects so they cannot be overlooked. Traditional authorities... because of their role and relationship to resources... you need their consent before you can subject a land area which is forested for REDD projects. Farmers in off-reserve areas, we will need them to invest in maintenance of existing tree resources and even planting new ones. Communities fringing forests have some roles that they play particularly the protection and giving them an incentive so they avoid illegal 
logging and mining. And the last one is the local government

agencies" (Consultant F, 2014).

Equity is relevant at national, regional, district and community levels, as resources are meant for public benefit at all scales, but particularly for the poor and disadvantaged in local forest fringe communities. The R-PP promotes the global safeguards stipulated in Paragraph 71 of 'Decision 1/CP.16' of the COP 16 in Cancun for indigenous peoples and local communities (UNFCCC, 2016). Having identified the subjects of equity in Ghana's REDD+ process, considerations include providing capacity enhancement, proper engagement and maximizing the benefits that accrue to these stakeholders. Special consideration is also intended for local rights, gender and vulnerable groups (landless, migrants without proper land documents, physically challenged farmers) by the R-PP. At the national level, the FC REDD+ Unit reportedly goes...

"...out of the way to look for who has been left out and bring them on-board. So as we go along, we get to know other groups that have not been part of the process and we bring them on board" (FC official A, 2014).

One purpose of SESA is to ensure that various social and gender equity goals are built into the REDD+ strategy options. It categorically states the intention to limit female discrimination by having express REDD+ benefits sharing arrangements for jointly implemented projects (Sal Consult, 2014). Spousal equity is at least in theory, intrinsic to the REDD+ process. Prior to Ghana's SESA process, IUCN championed gender concerns vis-à-vis equity. They led the discourse on gender in REDD+, organized meetings and workshops, and finally came up with a gender roadmap for the REDD+ process. This elevated the focus on gender and led to the establishment of a REDD+ gender desk officer at the FC.

Furthermore, in accordance with FCPF guidelines, special consideration is "given to livelihoods, rights, cultural heritage, gender, vulnerable groups, governance, capacity building and biodiversity" (Sal Consult, 2014; p.2). This narrows the scale at which equity subjects are considered. Economic needs are taken into consideration with specific priority for communities heavily dependent on forest resources such as cocoa farmers (Sal Consult, 2014). This is further evident in Ghana's development and pursuit of a REDD+ cocoa carbon jurisdictional programme. The push for alternative livelihoods by SESA for REDD+ communities includes animal rearing, aquaculture, bee keeping, non-farm business and other farm businesses that require irrigation and technological support. SESA calls for monitoring of alternative livelihood systems to make sure that incomes are sustainable.

This sub-section examined the Ghana REDD+ process premised on the question of who counts as a subject of equity? As laid out above, the national process highlights a focus on all forest stakeholders and the government in practice has, over the years, worked to include relevant stakeholders. It has been well established that communities and the heterogeneity (e.g. gender; culture) of these groups, that set them apart or bring them together, are a priority.

\subsection{Content}

\subsubsection{Procedural Equity}

Procedural equity is about the fairness of the REDD+ political process, which enmeshes stakeholder inclusion, networks, information and knowledge exchange. 
The Ghana REDD+ R-PP calls for the engagement of the major stakeholder groups "affected by, involved in implementation of, or otherwise interested in REDD+ regardless of sector" (p.26). Nuesiri (2015) discusses a similar approach of participation pursued by the UN-REDD programme, which is based on an "allaffected" principle. He intimates that without setting clear boundary conditions, a process of engagement that relies on the principle would be ineffective and impossible to monitor and evaluate vis-à-vis its objectives. What then can the Ghana process define as boundary conditions for its national policy level REDD+ engagement?

The need for information and adequate time to process the information and make decisions are key principles pushed by the R-PP for the development of effective REDD+ strategies. The FC, as the lead agency in Ghana's REDD+ process, has partnerships (formal and informal) with some CSOs in order to develop new knowledge among stakeholders. For instance, one CSO official indicated that they...
"actually worked with the $F C$ in raising awareness about REDD... some of our resources were put into raising awareness about what REDD is, about what it is going to entail. So we went through and contributed to the development of the consultation and participation of the R-PP".

Another interviewee expressed the informal relationship between FC and his CSO as symbiotic; whilst the NGO has resources which the government lacks to develop certain aspects of REDD+, the government has the political mandate to materialize REDD+ activities that are outside the NGO's remit. Examples of such relationships are the FC and Nature Conservation Research Centre's (NCRC) work on carbon infrastructure, which culminated in a national carbon map (Consultant F, 2014). There is also an IUCN-FC co-produced gender roadmap, and FC-Tropenbos Ghana partnership on general REDD+ research. These...

“...informal relationships between the REDD+ Secretariat and many NGOs... has been one of the very fruitful foundation of sharing resources between the REDD+ Secretariat and the NGOs... they are able to shape up the discussion such that whatever is being done by the NGO is in line with the national discussion and also meeting the NGOs own objectives"(EPA official A, 2014).

Some CSOs active in knowledge generation in REDD+ in Ghana spearhead areas of REDD+ interest through their own programmes as opposed to working reactively to government processes. These well-financed organizations, like IUCN, make impacts in the REDD+ forests and land use sector, and have relatively easier access to government officials and agencies that can influence processes or push new paths of REDD+ development than new/small actors, especially those at community level. For instance, according to CSO Official C...
"if you are not very strong organization that has links to government...your input into anything they discuss might not be taken into consideration. You have to be an IUCN or a loud mouth NCRC... or Forest Watch Ghana before you can get your inputs recognized by the government". 
Other interviewees recounted that the state, in running REDD+, did not create space for civil society inclusion. What was clear however, between the CSOs that felt engaged and those that did not, was the difference in how the organizations approach the process. Some CSOs create space for engagement whilst others wait to be invited. For instance, one interviewee mentioned how pro-active they were as a CSO in pushing for space to participate in the Ghana REDD+ process and facilitate community engagement. Nuesiri (2015) made a similar assertion that the active efforts of NGOs in Cross River State played a part in their inclusion in Nigeria's REDD+ design. An FC official stated that NGOs provide various information and knowledge exchange platforms, thereby supporting the foregoing claim. Conversely, another CSO interviewee said...

"it could also be because maybe, $\{$ we $\}$ as an organization have not really focused a lot in recent times on the climate discussion... one of our weaknesses \{is\} that we have focused too much on FLEGT to the neglect of REDD".

Some NGOs that are not part of the NRWG play more powerful roles in knowledge mediation and steering REDD+ in Ghana than other organizations on the NRWG. NGOs such as IUCN, NCRC, Civic Response, and Arocha are notable CSOs that have been responsible for knowledge transfer to actors within the wider forest and climate change sector. On the other hand...

“...the private sector doesn't even understand how to get involved in this [readiness] phase. They see it as a big risk, they don't understand what the actual return is"(Conservation NGO official B, 2014).

Knowledge exchange, information sharing and discussions between the timber industry and other stakeholders are lacking, unless such networking is spearheaded by the FC. Private sector (timber industry) access to REDD+ information and knowledge is therefore largely limited to that transferred by the FC. Another arm of the private sector, the carbon investors, in the initial stages, had a major role in the Ghana REDD+ process due to the 'learning by doing' approach that the FC was then pursuing. Third party organizations/investors were selected to pilot 7 REDD+ schemes to generate lessons that would feed into up-scaling decisions and approaches of the national REDD+ process. In 2015, the pilots were scrapped in pursuit of a jurisdictional approach that covers larger landscapes and a multitude of land uses (FC official A, 2016).

Ghana's REDD+ process is majorly structured around committees with various decision-making roles such as reviewing consultancy reports and drafting strategies. The committees comprise stakeholders who represent key REDD+ stakeholder groups identified in the initial phase of the R-PP formulation in 2009 by the FC. Some interviewees stated that members of these committees had REDD+ knowledge and information that they could not pass on to their respective constituencies because of limited resources (Consultant G, 2014). The high costs of local community inclusion in national decision-making processes is highlighted by Špirić et al. (2016) in their study of Mexico as an impeding factor to participation. This factor impacts the representational approach to consultation, as members of the committees do not have effective national level discussions with feedback from their wider stakeholder groups.

Aside from the committees and sub-committees, the government embarks on mass awareness raising, stakeholder consultations and targeted consultations. REDD+ 
consultations have been carried out across the ten administrative regions of Ghana, categorized into northern, middle-belt and southern zones (FC, 2010). Despite efforts to increase nationwide awareness and improve stakeholder engagement, which has led to the development of a REDD+ communication strategy by the FC, consultation is reportedly more skewed towards the national level (CSO official D, 2014). The REDD+ process has demanded more expert and targeted consultations on particular areas of REDD+ development. Ghana's interest in receiving payments for cocoa carbon under REDD+ means organizations such as the Cocoa Research Institute of Ghana, COCOBOD and Tuton are taken into consideration by the state in REDD+ decision-making.

Donors are key power players in the Ghana REDD+ implementation process chiefly due to their control of financial resources. For example, the World Bank donated the main readiness fund of US\$8.6 million for Ghana. This places the bank in an important position regarding the fund's use, and approving REDD+ activities for further fund access.

"That's part of the criticism of the finance that comes from the FCPF and the others. It dictates to you [recipient countries] where the money should go and they don't really take into consideration the things you would like to do with the money \{and this\} can create imbalance"(Consultant A, 2014).

The process of designing REDD+ is focused at the national level, with other stakeholder groups at sub-national level yet to be included. This finding mirrors that of Nuesiri's (2015) study, which found that local government authorities in Nigeria were excluded from the design of Nigeria-REDD+. Though stakeholder engagement in the Ghana process seems messy, the FC has progressed efforts to promote meaningful equitable engagement in REDD+.

\subsubsection{Distributive Equity}

Distributive equity examines the costs, risks and benefits of both monetary and nonmonetary allocations to various stakeholders based on REDD+ policy decisions and actions.

Ghana's REDD+ R-PP mentions creating an equitable benefit sharing system as part of the success factors of an effective REDD+ implementation programme. It states that stakeholders who engage their efforts towards REDD+ should realize benefits (FC, 2010). In the report (2014; p.23) of the commissioned benefit-sharing consultancy, the approach is to view benefits as "compensation for opportunity costs, funding for productive activities and REDD+ rent". The majority of stakeholders engaged in the benefits sharing study preferred an individual payment scheme to a fund-based scheme. In the Ghana R-PP, the forms of benefits considered fall within direct cash payments and non-cash benefits.

Workable benefit sharing systems are expected to generate alternative incomes and livelihoods for forest communities. In this regard, the Ghana RPP further pushes for assessment of the financial mechanisms needed to distribute any accruing revenue from REDD+. The commissioned study on benefit sharing for REDD+ examines four main pre-existing benefit sharing regimes in the forest sector: the Constitutional Timber Revenue benefits sharing, Community Resource Management Area (CREMA), Modified 
Taungya System (MTS) and Commercial Plantation benefits sharing (see Dumenu et al. (2014) for full analysis). The report weighs the aforementioned benefit sharing mechanisms against various elements, including equity, as summarized in Table 1 here.

\begin{tabular}{|l|l|}
\hline Benefit sharing mechanism & Equity perspective \\
\hline $\begin{array}{l}\text { Constitutional timber revenue benefit } \\
\text { sharing }\end{array}$ & $\begin{array}{l}\text { This is inequitable as some stakeholders } \\
\text { are left out of the arrangement. These } \\
\text { include farmers, forest communities and } \\
\text { land owners who are not 'Stools'. }\end{array}$ \\
\hline $\begin{array}{l}\text { Modified Taungya System benefits } \\
\text { sharing }\end{array}$ & $\begin{array}{l}\text { This is assessed to be equitable as it } \\
\text { includes all relevant stakeholders } \\
\text { engaged in plantation development and } \\
\text { forest management. }\end{array}$ \\
\hline Commercial Plantation revenue sharing & $\begin{array}{l}\text { Within the forest 'reserve', there is equity } \\
\text { as all stakeholders relevant to the } \\
\text { process are allocated benefits. However, } \\
\text { there is inequity with respect to the 'off- } \\
\text { reserve' areas because the state and the } \\
\text { communities are excluded from benefits } \\
\text { sharing. }\end{array}$ \\
\hline CREMA benefits sharing & $\begin{array}{l}\text { Equitable as it includes all relevant } \\
\text { stakeholders. }\end{array}$ \\
\hline
\end{tabular}

Table 1: Equity of existing benefits sharing as captured in the government report

Despite the recommendations of the commissioned study on benefit sharing models under REDD+, there is no explicitly agreed benefit-sharing framework for REDD+ in Ghana at the time of writing, and this makes it unclear what the equitability of the system will be.

In 2014, under SESA, an identification and distribution of possible costs, risks, tradeoffs and benefits was undertaken with respect to the then proposed REDD+ strategies. In general, SESA views REDD+ as an opportunity to improve the livelihoods of farmers, landowners and local communities. However, it also identifies risks to people such as charcoal producers and those dependent on wood fuel for energy, in the case that REDD+ leads to radical change in energy policy (FC, 2010). Furthermore, SESA classifies as part of the risks, inequitable carbon benefit distribution and capacity inequity between national level stakeholders and local decentralized stakeholders. In addition, further risks to equity identified include lack of transparency and accountability, elite capture of benefits and marginalization of women, the poor and the voiceless. Even in its early stages of implementation, some of these risks have reportedly manifested in countries such as Uganda, Kenya, and Tanzania. Some authors have highlighted cases of individual REDD+ projects and other carbon offset forestry projects that have violently evicted a number of people (Cavanagh et al., 2015); denied rights and access (Lyons and Westoby, 2014; Asiyanbi, 2016); prosecuted or fined for 'forest offences' (Asiyanbi, 2016); provided inequitable benefits (Bayrak and Marafa, 2016); and marginalized communities in decision-making (Beymer-Farris and Bassett, 2012). The Ghana SESA report calls for risks to be minimized in large part, via institutional frameworks that promote equity, including the establishment of grievance redress mechanisms.

The Ghana R-PP notes, from engaging stakeholders, that there are clear differences 
in expectations of the benefits and risks associated with REDD+. An interview with a key REDD+ actor from the private sector indicates that stakeholders in the group initially perceived the risk that REDD+ would hamper industries' access to raw material supply (timber). However, industry's perception of this risk ceased when the government assured industry that REDD+ would not affect their business or stake in forests, but rather benefit them as a new channel through which to make extra income.

Costs associated with REDD+ include investments in systems and technology for establishing emission baselines, monitoring, reporting and verification of carbon, and a benefits sharing framework, among other things. The FC has used funds from donors to meet the costs of some of these requirements and create an enabling environment. Some of these costs have also been borne by NGOs such as NCRC and IUCN. The private sector has refrained from bearing REDD+ readiness costs.

There is still a lot to be done in the Ghana REDD+ process in relation to establishing an equitable benefit-sharing framework that considers risks, costs and opportunities.

\subsubsection{Contextual Equity}

Contextual equity is about capabilities, access and power, as dictated by policies, laws and strategies.

There is reason to believe that Ghana's interest in the REDD+ policy mechanism is driven by the opportunity to improve its forest cover and revive its forest economy, as revenue from timber is set to decline. The 2012 FWP is oriented towards financing the forest sector through novel schemes. For instance, the policy views carbon to be valuable as a sustainable form of financing for Ghana's forests, and this interest is rooted in the economic gains to be earned from forests. Forest policy in Ghana has been retrofitted to suit existing programmes within the forestry sector, and REDD+ is no exception.

Stakeholder concerns expressed in the field interviews include the idea that REDD+ revenues and investment inflows into Ghana are no match for traditional forestry investments and revenues:

"If we add all the REDD investments that have come into the country, and the amount of money that the traditional investment of revenues that the forestry sector itself handles, you'll see that REDD is peanuts... to what extent would REDD be able to facilitate transformation in the forestry sector if REDD investment is not matching up the traditional investment revenue from forestry"(EPA official A, 2014).

The fear is that certain actors, who make money from the forest sector, will continue to control the forestry space and pursue revenue via commercial logging (Consultant F, 2014), which may compel the government to implement REDD+ on community lands as they collude in creaming off the economic gains from industrial logging on other lands such as protected areas. This is reflected in a statement by private sector interviewee $A$ :

"We have also expressed our concern about the implications of $R E D D$ as far as the industry is concerned and we have been assured [by FC] of our stake in there and also has made it clear to us that it's not going to be at the detriment of we being in 


\section{business".}

The situation is dire, as people in positions of power, such as DCEs, already use these positions to intimidate locals in less powerful positions. For example, a District Chief Executive called the police to arrest a local forest community dweller because the latter made a statement at a meeting about how the DCE was giving forest reserves to mining companies (CSO official E, 2014).

Operational difficulties around land rights and access to resources are key issues for Ghana's REDD+ process. Drawing on the R-PP and the Benefit Sharing Consultancy Report, the contextual elements impacting the creation of an equitable system of benefits sharing under REDD+ include unclear land/tree tenure, limited transparency and accountability in the management of benefits sharing, and un-defined conflict resolution mechanisms. In addition, in some areas in Ghana, men usually have dominant access to land for production while women face limited access and rather depend on the men economically (Sal Consult, 2014). Ghana's land tenure is pluralistic and complex (Dumenu et al., 2014). The tenurial complexity of bundles of rights under customary law plus undocumented land rights pose risks to equity for REDD+ implementation. Certainly in the case of Ghana where REDD+ implementation is focused on the cocoa-growing landscape, tenure poses risks to farmers (usually migrants) who have entered into some form of share-cropping arrangements with land owners, which is not secure in many ways (Isyaku et al., 2017). Further key observations have been raised by Isyaku et al. (2017) on challenges linked to tenure, despite the introduction of tree registration approaches to improve tenure for farmers. Because of the share-cropping arrangements, the owner of the land on which the farmer has planted the registered tree can claim the same tree as the farmer, and the Paramount Chief who oversees all traditional lands in his area, can also lay claim to the same tree (Isyaku et al., 2017).

The new dimension of carbon tenure adds to the conundrum. A number of key interviewees expressed the opinion that REDD+ has been overburdened with discussions around carbon. With the initial focus on carbon, the REDD+ process was heavily science-laden with prioritized activities including instituting carbon monitoring, reporting and verification systems, setting emission baselines, among other things. For instance, the 2012 FWP on developing public institutions and civil society capacities to engage in responding to threats and risks of climate change seemingly prioritizes enacting the "necessary legislations to guide allocation of carbon rights and related matters" and supporting "training and education in forest resource management at district levels in carbon rights allocation" (p.21). In dealing with timber trees, the physical attributes of the resource make it relatable to communities in terms of their governance, management, sales and price. Carbon, on the other hand, has a characteristic of invisibility, which hampers the ability of locals to effectively engage in governance, sale and pricing, which are regulated at a global level.

Ghana's constitution vests all minerals and naturally occurring trees in the President as the Head of State to hold in trust for the people of Ghana. If carbon is regarded as part of trees, then it would be tied into state ownership of timber trees considered a naturally occurring economic resource (Dumenu et al., 2014). Under Ghana's REDD+ process, it is proposed that forest carbon could be treated as separate from the trees or biomass in which it is stored. In this case, the laws governing natural resources would not be applicable to the resource as one vested in the state (Dumenu et al., 2014). There is advocacy to reform ownership of naturally occurring trees to be vested in persons with management, exclusion and alienation rights to trees and land, and treating carbon as tied to the trees and soil in order to ensure 
equity. Land (including natural resources) and access issues impact the enabling environment for REDD+ implementation and benefit sharing. The rights the government has over trees disincentivizes farmers to keep naturally regenerating trees on their land.

The benefits distribution, as specified in the constitution, is also inequitable given that it is not, largely, shared among all parties. Government organizations (FC and OASL) are given preference to take the first shares of forest revenue, and the remainder is treated as one hundred percent of the revenue, which is then shared in proportion to the remaining stakeholders. The constitution skews the benefits to the government and further raises questions of transparency and accountability within the process, because the wording of the basis for the traditional authority and 'Stool' shares are vague.

Chieftaincy, together with traditional councils as established by customary law, is a strong institution in Ghana recognized by the constitution in article 270(1) (Sal Consult, 2014). Chiefs, therefore, as landholders, have very important stature within the land use-REDD+ nexus. Some interviewees regarded the role of chiefs in REDD+ to be problematic and insisted that the chiefs had been given too much power in the process. Other interviewees called for chiefs to be roped in more closely in championing the objectives of REDD+ so they would not engage in activities that interfere disadvantageously with REDD+.

The field interviews revealed some government offices were territorial about their mandates and unwilling to work with other offices or other sectors. This subtle struggle for power and control exists, for example, between the Ministry of Environment, Science, Technology and Innovation and the MLNR, as alluded to by some interviewees, but more strongly by the official from the Ministry of Agriculture. Bastakoti and Davidsen (2017) found similar results in their observation and documentary review of Nepal's REDD+ policy arena. Moreover, not all ministries in Ghana are aware of REDD+, and for ministries who engage in the REDD+ space, ministers attend meetings and make statements which are not necessarily from a place of knowledge or commitment but intended for political gain (Conservation NGO official $B, 2014$ ). Policies and regulations are still segmented in silos, and need to be coordinated as REDD+ affects, and is affected by, sectors beyond the forest sector. This cross-sectoral engagement is made no easier by being based on existing poor organizational coordination. A case in point is the Forest Preservation Programme (FPP) that was handled by another office in the FC and did not in any way collaborate or liaise with the designated FC REDD+ Unit in its implementation. The Japanese government sponsored the FPP to generate forest cover data for Ghana. According to a key government informant, the maps generated are of minimal use to the REDD+ Unit.

\section{Discussion}

Ghana's priorities for its natural resources are evidently linked to economic growth and development, with forests having fuelled the nation's development. This role of forests in economic development is threatened by the decreasing forest cover, which means less timber to be exploited and sold. Thus the country has positioned itself to take advantage of new initiatives and sources of forest finance such as REDD+ and other results-based payments. This strategic positioning on the non-consumptive values of Ghana's forest resources is effectively the direction that the revised 2012 FWP seeks to achieve. 
Equity has clearly been a focus in the Ghana REDD+ readiness process as far as documents like the R-PP; SESA; and benefits sharing consultancy report are concerned. Equity has been mainly defined by these documents, given the minimal guidance on equity parameters by the UNFCCC (Ituarte-Lima et al., 2014). Despite a commitment at policy level to achieve equitable REDD+, it is, in practice, not clear whether the implementation arrangements are leading to its achievement, or the extent of the predictability of the on-ground equity impacts (FC, 2010). Based on analysis of stakeholder insights and documents, the study shows that the government of Ghana is focused on the financial and economic gains from opportunities such as REDD+ but with little advancement in dealing with equity vis-àvis existing policy gaps and weaknesses.

REDD+ impacts vary across stakeholder groups, as interests in forests are diverse (Agrawal and Gibson, 1999). The legitimacy of REDD+ therefore rests in part on the equity implications of the mechanism's instituted policies, actions and measures for each stakeholder group. This is an insight that only people within each stakeholder category can provide through their participation and feedback to the FC as the lead authority on REDD+. The challenge in Ghana is that there is no institutionalized process of stakeholder engagement, making the government convened stakeholder meetings the main platform for submitting views, a process without which some stakeholders would be disadvantaged in influencing REDD+ decisions. This raises an equity concern. Within the civil society sector, well resourced and already connected organizations create their own spaces of engagement and make inputs into the national process, while the relatively less well resourced and least connected organizations, including community-based organizations, are at a disadvantage. The prioritized commercialization of the land and natural resource sector preceding Ghana's REDD+ process, dictates, to some extent, the power distribution amongst REDD+ stakeholders which impacts procedural and distributive equity (Nathan and Pasgaard, 2017). A limitation of this study lies in its inability to analyze what Špirić et al. (2016; p.2) call 'output legitimacy' - "the level of actors' acceptance of adopted decisions and the outcomes of their implementation". There is also abundant room for further progress in determining how an institutionalized system is best placed to promote participatory equity, and its monitoring and evaluation.

"Knowledge is generated through interaction" (Ponte and Cheyns, 2013; p.3) which makes managing a process of stakeholder interaction essential to propelling the achievement of REDD+ objectives (Saxena, 2011). However, it seems there is no real depth to the opportunity for stakeholders to voice their interests or concerns, or shape the decisions made. These limited forms of participation, restrict stakeholders' knowledge and therefore power in the process (Gaventa and Cornwall, 2006).

Having balanced knowledge transfer between stakeholder groups, and within groups, needs careful consideration. Stakeholder 'consultation and participation' seems to be a term used only loosely in Ghana's REDD+ governance. In practice, the process is one of stakeholder representation, as seen in the NRWG and the myriad of newly established decision-making committees. The voices that are expressed belong to various stakeholder groups, but are often limited to individual decisions and views, as opposed to a reflection of the collective voices of stakeholder groups. Suiseeya (2016) more recently argues that REDD+ debates are too focused on relatively simple visions of either distributive or procedural justice, and pay too little attention to the core recognitional justice concerns of REDD+. Complexifying the concepts of justice in the debates on REDD+, she suggests, can illuminate the possibilities for a diversity of alternative perspectives to generate new institutional design ideas for 


\section{REDD+.}

Under REDD+, unlike traditional forest management, there is an increasing trend for privatizing development ideas that the state is ordinarily expected to lead on. Ghana's government uses experts to assist in the REDD+ policy mechanism via commissioned consultancies. This allows for the creation and flow of ideas and knowledge. Several questions remain unanswered about what impact the background and world-view of commissioned consultants have, and how they direct global environmental governance initiatives such as REDD+. In the face of failed consultancies, this matters, because of the huge finances pumped into such consultancies, when funding for REDD+ is uncertain and insufficient (International Sustainability Unit, 2012). With regard to equity, the backgrounds of consultants are essential to how they understand and construct the knowledge that leads to prescriptions for localizing REDD+ policies and actions.

The REDD+ benefit-sharing proposal addresses costs and risks as well as benefits. Benefits are seen as key to achieving a successful REDD+ mechanism, as they are expected to sustain stakeholder effort and interest. Despite this, Ghana's readiness process has not been able to establish what the expected risks and benefits are for each stakeholder group. However, as initial steps, the readiness process has examined the equity of possible benefit sharing models primarily by focusing on whether all relevant stakeholders are captured as beneficiaries. This study maintains that being a recognized beneficiary does not guarantee equitable distribution of benefits. Rather, a deeper level of analysis is warranted at policy level to identify equitable distribution amongst actors.

REDD+ poses risks to local community livelihoods dependent on forests, as it demands a change in the manner in which they relate to the resource (Leggett and Lovell, 2012). On the other hand, the immediacy of everyday survival for forest dependent local communities, threatens the degree to which REDD+, as a relatively long-term source of income, is attractive to them. Discussions about REDD+ need to be held within the greater framework of sustainability, which means considering the interface forests have with other sectors, including agriculture, community development, energy, and water. In addition, spatial differences created by the myriad of ethnic groups, livelihoods, cultures and norms across the country, necessitate SESA being carried out for specific REDD+ areas. Issues that may have been lost in the wider SESA process at the strategic national level can then be captured. Within the context of broader conceptualizations of justice in REDD+ McDermott et al. (2013) accommodate social equality by focusing on relational aspects (Fraser, 2001) rather than on the aspect known as 'recognition of difference', i.e. cultural identity, values, and politics of difference (Fraser, 2001). McDermott et al. (2013) adopt a material focus to justice as set out in pre-valued set of standards (procedural, distributive and contextual) to eliminate unjustified disparities in opportunities of those involved (Fraser, 2001). The standards that are applied within their framework help to pinpoint disparities between what is morally thought of as fair among varying views of the actors and what is considered 'good'.

Traditional forestry in Ghana has, since the early 1900s, been about scientific forestry, relying on measurements and data to ensure sustainable supply of forest products and a permanent forest estate (Hansen and Lund, 2017). Though REDD+ relies on measurements, data and figures, its demands differ because of what is measured, i.e. carbon (Stephan, 2013). REDD+ therefore requires new knowledge generation and capacity building (Bumpus and Liverman, 2011). Such knowledge requirements of new methodologies require capacity building and time. Furthermore, stakeholders that do not have the resources to build capacity, or contribute to the 
new knowledge needed, do not remain relevant to the REDD+ process. The technical nature of REDD+ makes it largely removed from the understanding and involvement of the locals. For example, with timber exploitation, physical trees are sold and taking stock is straightforward, whereas, in contrast, REDD+ requires the establishment of baselines of a non-visible, non-physical 'commodity' (carbon), and measuring and validating sequestered carbon.

Informal relationships have emerged around REDD+ concerning research, knowledge creation, establishing and implementing protocols, and technical knowhow. This is quite different to traditional forestry where informal relationships influence access to concessions and timber trees (Hansen et al., 2009). Resource sharing is a key characteristic of the informal relationships between FC and NGOs in REDD+. Such relationships between FC and others, can engender a kind of bottomup feedback loop, or entrench power in the hands of a few who engage in the process to drive their own agenda. There is no doubt that NGOs, especially those international in nature, are essential to REDD+ because of the resources they wield, their political connectedness and control over technology and knowledge (Newell et al., 2012). The dilemma however, is how they exercise this power.

The policy and strategy narratives around REDD+ account for and promote equity concerns as reflected in, for instance, the adoption of safeguards, and the Forest and Wildlife Policy of 2012, which considers inter-generational equity. However, implementation typically demonstrates that economic prioritization is in contention with achieving equity for all stakeholders, natural resources and the environment.

\section{Conclusion}

In conclusion, the government of Ghana is, on paper, pursuing an equitable outcome with respect to benefits and ensuring that all actors, especially local forest communities, are subjects of the equity it seeks to achieve through REDD+. Nevertheless, in practice, REDD+ is much messier in achieving desired equitable processes and outcomes. The study shows procedural (including stakeholder knowledge and capacity) and contextual (political economy/economic interests and forces) limitations, which impact the achievement of distributive equity. Part of achieving equitable REDD+ requires processes that bring new knowledge to a wider set of REDD+ actors, beyond the representative approach currently adopted.

In this paper, McDermott et al. (2013) 'equity framework' provides a useful lens through which to understand the outcomes of the mediation of REDD+ at the national level in Ghana. Its value lies in further monitoring Ghana's progress, as the first generation of implementation projects kick off. McDermott et al's (2013) framework has been good in showcasing how remnants of Ghana's colonial laws and policies create an uneven playing field, which impedes distributive and procedural equity at the local level under a REDD+ regime. In addition, this study has shown that REDD+ knowledge in Ghana distributes power through deepening stakeholder capacity to make informed decisions and contributions. However, the framework does not adequately highlight the issue of 'knowledge' and its critical role in determining the distribution of power within any (environment/REDD+) governance process. Knowledge and capacity may give a wider set of relevant stakeholders a 'voice-atthe-table'. Despite the fact that having a voice in the REDD+ process can ensure stakeholders' relevance, incentivize continued engagement and contribute to the achievement of equity, this is largely dictated by the existing contextual elements. Therefore, although national REDD+ processes may formulate decent policies and 
strategies, a critical foundation to achieving equity, is addressing limiting contextual factors (usually historical) in other policies, laws, capabilities, access and power. 


\section{Acknowledgements}

Our gratitude goes to Nick Jones for proof reading an earlier version of this paper. Further appreciation goes to Hilma Manan for constantly providing up-to-date versions of REDD+ documents and policies as and when they were produced in the Ghana REDD+ process.

\section{Funding}

This research was supported by the Commonwealth Scholarship Commission, UK, as part of a doctoral research.

\section{References}


Agrawal, A., \& Gibson, C. C., 1999. Enchantment and Disenchantment: The Role of Community in Natural Resource Conservation. World Development, 27(4), 629-649. http://doi.org/10.1016/S0305-750X(98)00161-2

Angelsen, A., Brockhaus, M., Sunderlin, W. D., \& Verchot, L. V., 2012. Analysing REDD +: challenges and choices.

Arhin, A. A. (2015). Halting deforestation to advance sustainable development: Progress, prospects and challenges of REDD+ Readiness in Ghana. In D. Reyes (Ed.), Sustainable Development: Processes, Challenges and Prospects. Nova Publishers. http://doi.org/10.13140/RG.2.1.2615.6566

Asiyanbi, A. P. (2016). A political ecology of REDD +: Property rights, militarised protectionism, and carbonised exclusion in Cross River. Geoforum, 77, 146-156. http://doi.org/10.1016/j.geoforum.2016.10.016

Asiyanbi, A. P., Arhin, A. A., \& Isyaku, U. (2017). REDD+ in West Africa: Politics of design and implementation in Ghana and Nigeria. Forests, 8(78).

http://doi.org/10.3390/f8030078

Bastakoti, R. R., \& Davidsen, C. (2017). Framing REDD + at national level: Actors and discourse around Nepal's policy debate. Forests, 8(57).

http://doi.org/10.3390/f8030057

Baxter, P., \& Jack, S., 2008. Qualitative Case Study Methodology: Study Design and Implementation for Novice Researchers. The Qualitative Report, 13(4), 544-559. Retrieved from http://nsuworks.nova.edu/tar/vol13/iss4/2 (27/01/17)

Bayrak, M. M., \& Marafa, L. M. (2016). Ten years of REDD+: A critical review of the impact of REDD+ on forest-dependent communities. Sustainability, 8(620), 1-22. http://doi.org/10.3390/su8070620

Beymer-Farris, B. a., \& Bassett, T. J. (2012). The REDD menace: Resurgent protectionism in Tanzania's mangrove forests. Global Environmental Change, 22(2), 332-341. http://doi.org/10.1016/j.gloenvcha.2011.11.006

Boucher, D., Elias, P., Faires, J., \& Smith, S., 2014. Deforestation Success Stories: Tropical Nations where Forest Protection and Reforestation Policies have Worked. Cambridge, MA: Union of Concerned Scientists. Online at Www.Ucsusa.Org/forestsuccess, Accessed on December, 8, 2014.

Boyd, E., \& Folke, C., 2012. Adapting Institutions: Governance, complexity and social-ecological resilience. Cambridge University Press

Bumpus, A., \& Liverman, D. M., (2011). Carbon Colonialism? Offsets, greenhouse gas reductions, and sustainable development. In R. Peet, P. Robbins, \& M. J. Watts (Eds.), Global Political Ecology (pp. 203-224). Routledge.

Cavanagh, C. J., Vedeld, P. O., \& Traedal, L. T. (2015). Securitizing REDD+? Problematizing the emerging illegal timber trade and forest carbon interface in East Africa. Geoforum, 60, 72-82. http://doi.org/10.1016/j.geoforum.2015.01.011 
Chomba, S., Kariuki, J., Friis, J., \& Sinclair, F., 2016. Land Use Policy Roots of Inequity: how the implementation of REDD + reinforces past injustices, 50, 202-213.

Domson, O., \& Vlosky, R. P., 2007. A Strategic Overview of the Forest Sector in Ghana. Retrieved from

http://www.lfpdc.Isu.edu/publications/working_papers/wp81.pdf (accessed 27/01/2017)

Dumenu, W., Derkyi, M., Samar, S., Oduro, K., John, M., Penstil, S., ... Obeng, E., 2014. Benefit Sharing Mechanism for REDD+ Implementation in Ghana Consultancy Report.

FAO, 2013. Implementing the Non-legally Binding Instrument on All Types of Forests. http://www.fao.org/docrep/019/mi749e/mi749e.pdf (accessed 27.01.2017)

Forestry Commission, 2010. Readiness Preparation Proposal Ghana. Accra

Forestry Commission, 2014. Forest Carbon Partnership Facility Carbon Fund Emission Reductions Program Idea Note for Ghana. Accra

Forestry Commission, 2008. The Forest Carbon Partnership Facility Readiness Plan Idea Note for Ghana. Accra

Forestry Commission, 2016. Ghana REDD + Strategy 2016-2035. Accra

Forsyth, T., \& Sikor, T. (2013). Forests, development and the globalisation of justice. The Geographical Journal, 179(2), 114-121. http://doi.org/doi: 10.1111/geoj.12006

Fraser, N. (2001). Recognition without Ethics. Theory, Culture and Society, 18(2-3).

Gaventa, J., \& Cornwall, A., 2006. Challenging the Boundaries of the Possible:

Participation, Knowledge and Power. IDS Bulletin, 37(6), 122-128.

http://doi.org/10.1111/j.1759-5436.2006.tb00329.x

Groom, B., \& Palmer, C., 2012. REDD + and rural livelihoods. Biological

Conservation, 154, 42-52. http://doi.org/10.1016/j.biocon.2012.03.002

Hansen, C., Lund, J., \& Treue, T., 2009. Neither fast, nor easy: the prospect of Reduced Emissions from Deforestation and Degradation (REDD) in Ghana. International Forestry Review, 11(4), 439-455

Hansen, C. P., \& Lund, J. F. (2017). Imagined forestry: The history of the scientific management of Ghana's High Forest Zone. Environment and History, 23(1). http://doi.org/10.3197/096734017X14809635325548

Honneth, A. (1992). Integrity and disrespect: Principles of a conception of morality based on the Theory of Recognition. Political Theory, 20(2), 188-9.

Honneth, A. (1995). The struggle for recognition: The moral grammar of social conflicts. trans Joel Anderson. Cambridge: Polity Press.

Indufor, 2015. Development of Reference Emissions Levels and Measurement, Reporting and Verification System in Ghana. 
International Sustainability Unit, 2013. Interim REDD+ Finance: status and ways forward for 2013-2020. http://www.pcfisu.org/wp-content/uploads/2012/11/Nov-2012Interim-REDD+-Finance-Current-Status-and-Ways-Forward-2013-2020-PrincesRainforests-Project.pdf (accessed 25.01.2017).

Isyaku, U., Arhin, A. A., \& Asiyanbi, A. (2017). Framing justice in REDD+ governance: centring transparency, equity and legitimacy in readiness implementation in West Africa. Environmental Conservation, 44(3), 212-220. http://doi.org/10.1017/S0376892916000588

Ituarte-Lima, C., McDermott, C. L., \& Mulyani, M., 2014. Assessing Equity in National Legal Frameworks for REDD+: The Case of Indonesia. Environmental Science \& Policy, 44, 291-300. http://doi.org/10.1016/j.envsci.2014.04.003

Kashwan, P., 2015. Forest Policy, Institutions, and REDD+ in India, Tanzania, and Mexico. Global Environmental Politics, 15(3), 95-117. http://doi.org/10.1162/GLEP

Kashwan, P., 2016. Power asymmetries and institutions : landscape conservation in central India. Regional Environmental Change. http://doi.org/10.1007/s10113-0150925-8

Leggett, M., \& Lovell, H., 2012. Community perceptions of REDD+: a case study from Papua New Guinea. Climate Policy, 12(1), 115-134.

http://doi.org/10.1080/14693062.2011.579317

Leggett, M., \& Lovell, H., 2012. Community perceptions of REDD + : a case study from Papua New Guinea. Climate Policy, 12(1), 115-134.

http://doi.org/10.1080/14693062.2011.579317

Lockwood, M., Davidson, J., Curtis, A., Stratford, E., \& Griffith, R., 2010. Governance Principles for Natural Resource Management. Society \& Natural Resources: An International Journal, 23(10), 986-1001. http://doi.org/10.1080/08941920802178214

Lyons, K., \& Westoby, P. (2014). Carbon colonialism and the new land grab: Plantation forestry in Uganda and its livelihood impacts. Journal of Rural Studies, 36, 13-21. http://doi.org/10.1016/j.jrurstud.2014.06.002

Mahanty, S., \& McDermott, C. L., 2013. How does "Free, Prior and Informed Consent" (FPIC) Impact Social Equity? Lessons from Mining and Forestry and their Implications for REDD+. Land Use Policy, 35, 406-416.

http://doi.org/10.1016/j.landusepol.2013.06.014

Marfo, E., 2015. The illusion of democratic representation in the REDD readiness consultation process in Ghana (15). Responsive Forest Governance Initiative. Dakar. http://doi.org/10.1017/CB09781107415324.004

Marfo, E., Danso, E., \& Nketiah, S. K., 2013. Analysis of Linkages and Opportunities for Synergies between FLEGT, REDD+ and National Forest Programmes in Ghana.

McDermott, C. L., 2013. Certification and Equity: Applying an "Equity Framework" to Compare Certification Schemes across Product Sectors and Scales. Environmental Science \& Policy, 33(0), 428-437. http://doi.org/10.1016/j.envsci.2012.06.008 
McDermott, M., Mahanty, S., \& Schreckenberg, K., 2013. Examining equity: A multidimensional framework for assessing equity in payments for ecosystem services. Environmental Science \& Policy, 33, 416-427. http://doi.org/10.1016/j.envsci.2012.10.006

MEST, 2010. Ghana Goes for Green Growth Discussion document - Summary Climate change in Ghana. Retrieved from http://cdkn.org/wpcontent/uploads/2011/04/NCCPF-Summary-FINAL.pdf

Ministry of Lands and Natural Resources, 2012. Ghana Investment Plan for the Forest Investment Program.

Ministry of Lands and Natural Resources, 2012. Ghana Forest and Wildlife Policy. Accra.

Ministry of Science Technology and Innovation, 2013. Ghana National Climate Change Policy. Accra.

Nathan, I., \& Pasgaard, M. (2017). Is REDD+ effective, efficient, and equitable? Learning from a REDD + project in Northern Cambodia. Geoforum, 83, 26-38. http://doi.org/10.1016/j.geoforum.2017.04.020

Newell, P., Maxwell, B., \& Boyd, E., 2012. The New Carbon Economy: Consttution, Governance and Contestation. Wiley-Blackwell.

Newell, P., Pattberg, P., \& Schroeder, H., 2012. Multiactor Governance and the Environment. The Annual Review of Environment and Resources, 37, 365-387. http://doi.org/10.1146/annurev-environ-020911-094659

Norad, 2016. Real-time evaluation of the Government of Norway's International Climate and Forest Initiative: literature review and programme theory.

Norton Rose LLP, 2010. Forest carbon rights in REDD + countries : a snapshot of Africa.

Nuesiri, E. O. (2015). Representation in REDD: NGOs and chiefs privileged over elected local government in Cross River State, Nigeria (RFGI No. 11). Dakar. Retrieved from http://www.codesria.org/spip.php?article2322\&lang=fr

Ostrom, E.,1990. Governing the Commons: The evolution of institutions for collective action. Cambridge University Press.

Peet, R., Robbins, P., \& Watts, M. J., 2011. Global Political Ecology. (R. Peet, P. Robbins, \& M. J. Watts, Eds.). London and New York: Routledge.

Penna-firme, R., \& Brondizio, E. (2007). The risks of commodifying poverty: Rural communities, Quilombola identity, and nature conservation in Brazil. Habitus, 5(2), 355-373.

Ponte, S., \& Cheyns, E., 2013. Voluntary standards, expert knowledge and the governance of sustainability networks, 1-19. 
Quesada-Aguilar, A., \& Franks, P., 2015. Applying three dimensions of equity to REDD+. London: IIED. http://pubs.iied.org/17321IIED (accessed 15.01.17).

Rantala, S., Kontinen, T., Korhonen-Kurki, K., \& Mustalahti, I., 2015. Equity in REDD+: Varying logics in Tanzania. Environmental Policy and Governance, 25(3), 201-212. http://doi.org/10.1002/eet.1669

RECOFTC, 2015. Equity in forests and REDD +: An analysis of equity challenges as viewed by forestry decision-makers and practitioners in Cambodia, Lao PDR and Vietnam.

REDD-net, 2011. A Framework for Defining Equity. www.redd-net.org (accessed 30.11.16).

Ribot, J. C., \& Larson Anne M., 2012. Reducing REDD Risks: Affirmative Policy on an Uneven Playing Field. International Journal of the Commons, 6(2), 233-254.

Richards, L.,1999. Data Alive! The Thinking Behind NVivo. Qualitative Health Research, 9(3), 412-428.

Richards, L., 2000. Using NVivo in Qualitative Research. In P. Bazeley \& L. Richards (Eds.), The NVivo Qualitative Project Book (pp. 255-260). Sage Publications.

Saeed, A-R., McDermott, C., \& Boyd, E., 2017. Are REDD+ community forest projects following the principles for collective action as proposed by Ostrom? International Journal of the Commons. 11(1). http://doi.org/10.18352/ijc.700

SAL Consult, 2014. REDD+ Strategic Environmental and Social Assessment. Accra.

Saxena, N. C., 2011. What is meant by people's participation? In A. Cornwall (Ed.), The participation reader (pp. 31-33). London: Zed Books. Retrieved from http://lstlss.ucl.ac.uk/course-materials/BENVGSD2 63001.pdf

Schlosberg, D., \& Carruthers, D. (2010). Indigenous struggles, environmental justice, and community capabilities. Global Environmental Politics, 10(4).

Jovanka, Š., Corbera, E., Reyes-Garcia, V., \& Porter-Bolland, L. (2016). A Dominant voice amidst not enough people: Analysing the legitimacy of Mexico's REDD+ readiness process. Forests, 7(313). http://doi.org/10.3390/f7120313

Stephan, B. (2013). How to trade "not cutting down trees": a governmentality perspective on the commodification of avoided deforestation. In C. Methmann, D. Rothe, \& B. Stephan (Eds.), Interpretive approaches to global climate governance: (De) constructing the greenhouse (1st ed., pp. 57-71). Abingdon: Routledge.

Suiseeya, K. R. M. (2016). Transforming justice in REDD+ through a politics of difference approach. Forests, 7(300), 1-14. http://doi.org/10.3390/f7120300

Symon, G., \& Cassell, C., 2012. Qualitative Organizational Research: Core methods and current challenges. (G. Symon \& C. Cassell, Eds.). London: Sage Publications.

Taylor, C. (1994). The Politics of Recognition. In A. Gutmann (Ed.), Multi-culturalism: Examining the politics of recognition. Princeton NJ: Princeton University Press. 
Teddlie, C., \& Yu, F., 2007. Mixed Methods Sampling: a typology with examples. Journal of Mixed Methods Research, 1(1), 77-100.

http://doi.org/10.1177/2345678906292430

Teye, J. K., 2011. A Chronological Assessment of Ghana's Forestry Policies in Precolonial and Colonial Era: lessons for forest management in contemporary Ghana. African Journal of Social Sciences, 1(2), 125-139.

Teye, J. K., 2008. Forest Resource Management in Ghana: an analysis of policy and institutions. https://core.ac.uk/download/pdf/43838.pdf (accessed 27.01.17)

Tilahun, M., Damnyag, L., \& Anglaaere, L. C. N. (2016). The Ankasa Forest Conservation Area of Ghana: Ecosystem service values and on-site REDD+ opoortunity cost. Forest Policy and Economics, 73, 168-176.

http://doi.org/10.1016/j.forpol.2016.08.011

UNFCCC., 2016. Reducing Emissions from Deforestation and Forest Degradation in Developing Countries Factsheets. REDD+ web platform. http://redd.unfccc.int/factsheets.html (accessed 01.09.2016).

Vijge, M. J., Brockhaus, M., Gregorio Di, M., \& Muharrom, E., 2016. Framing national REDD + benefits, monitoring, governance and finance: a comparative analysis of seven countries. Global Environmental Change, 39, 57-68.

http://doi.org/10.1016/j.gloenvcha.2016.04.002

Walsh, M., 2003. Teaching Qualitative Analysis Using QSR NVivo. The Qualitative Report, 8(2), 251-256. Retrieved from http://nsuworks.nova.edu/tar/vol8/iss2/6 (accessed 27.01.2017)

Welsh, E., 2002. Dealing with Data: using NVivo in the Qualitative Data Analysis Process 1. Forum: Qualitative Social Research, 3(2), Art. 26. http://nbnresolving.de/urn:nbn:de:0114-fqs0202260 